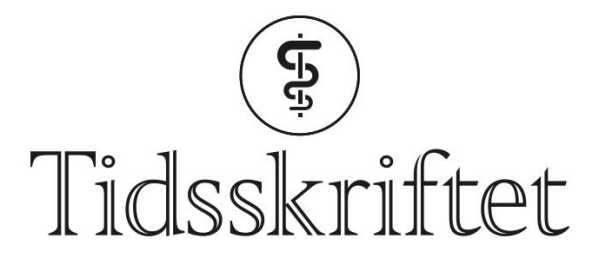

DEN NORSKE LEGEFORENING

\title{
Apoptotiske celler hemmer inflammasjon
}

FRA ANDRE TIDSSKRIFTER

HAAKON B. BENESTAD

Universitetet i Oslo

Programmert celledød kan aktivere celler i omgivelsene til den døende cellen.

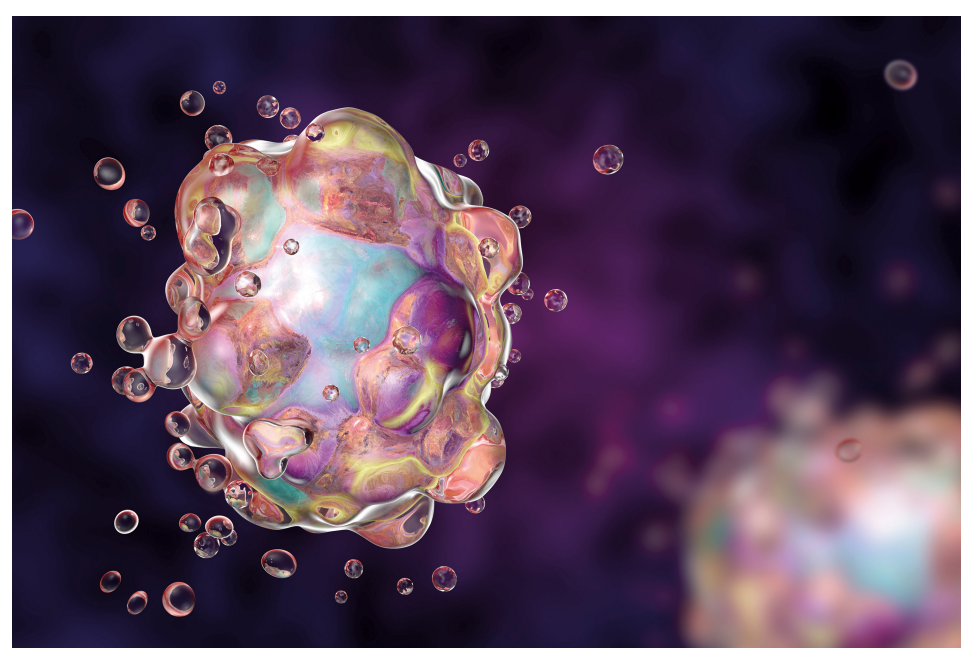

En celle i et tidlig stadie av programmert celledød. Illustrasjon: Science photo library/ NTB Scanpix

Omsetningen av celler er svært stor, både under vekst og ved stasjonære forhold. Det er antatt at mer enn $90 \%$ av cellene dør programmert (apoptose), mens resten kan dø av celleskade (nekrose). Nekrosen kan sette i gang en betennelsesreaksjon i omgivelsene. Eksempelvis vil omtrent en million nøytrofile granulocytter $\mathrm{d} ø \mathrm{i}$ apoptose hvert sekund hos et menneske - heldigvis uten at det slippes ut skadelige molekyler beregnet på mikrober, slik det kunne skjedd ved nekrose.

En ny studie har kartlagt hvordan apoptotiske celler ikke bare beskytter mot inflammasjon, men også hemmer den og stimulerer vevsregenerasjon (1). Ved apoptose forblir cellemembranen intakt så lenge at cellen kan utskille metabolitter som kan tenkes å påvirke omgivelsene, før cellerestene fagocyteres og brytes ned.

I studien ble primære celler og cellelinjeceller fra musethymocytter, musebenmargsderiverte makrofager og humane Jurkat T-celler drept apoptotisk ved hjelp av UV-bestråling, anti-Fas-antistoff eller antrakstoksin. Cellenes metabolittsekret og metabolom ble analysert med massespektrometri. Noen av sekresjonsproduktene var felles i de ulike oppsettene, med utskillelse via panneksin 1-kanaler, som ble åpnet i apoptotiske celler av en kaspase. Sammen induserte sekretene spesifikke genprogrammer i friske 
naboceller, noe som fremmet anti-inflammasjon, anti-apoptose, $\varnothing \mathrm{kt}$ motilitet og differensiering av makrofager henimot M2-renovasjonstypen. En blanding av disse sekresjonsproduktene, injisert daglig til mus over en 1-2 ukers periode, hadde inflammasjonsdempende virkning på artritt og på en avstøtningsreaksjon mot en transplantert lunge. Spermidin, guanosinmonofosfat og inosinmonofosfat samarbeidet $i$ disse reaksjonene.

- Denne forskningsgruppen har tidligere vist at apoptotiske celler frigjør såkalte «finn meg»-signaler gjennom panneksin 1-kanaler for å rekruttere makrofager, forteller Guttorm Haraldsen, som er professor i patologi ved Universitetet i Oslo.

- Nå har gruppen tatt konseptet et betydelig steg videre og vist at slik frigjøring også gjelder anti-inflammatoriske metabolitter, sier Haraldsen, som mener det blir spennende å se om funnene kan overføres til nye behandlingsprinsipper. Han påpeker at en av komponentene i metabolittblandingen som ble brukt i inflammasjonsmodellen, har mye svakere effekt hos mennesker enn hos mus.

- Slike forskjeller mellom dyrearter endrer likevel ikke på hovedprinsippet, som synes å være at apoptose er en aktiv anti-inflammatorisk prosess indusert av flere metabolitter $\mathrm{i}$ fellesskap, sier Haraldsen.

\section{LITTERATUR:}

1. Medina CB, Mehrotra P, Arandjelovic S et al. Metabolites released from apoptotic cells act as tissue messengers. Nature 2020; 580: 130-5. [PubMed][CrossRef]

Publisert: 29. juni 2020. Tidsskr Nor Legeforen. DOI: 10.4045/tidsskr.20.0406 (C) Tidsskrift for Den norske legeforening 2020. Lastet ned fra tidsskriftet.no 